\title{
Making All the Gears Drive the Machine: New Library Collections and Ser- vices for Starting a Mechanical Engineering Program
}

\section{Ms. Kelly Peterson-Fairchild, Dixie State University}

Kelly Peterson-Fairchild is the Dean of Library \& Learning Services at Dixie State University. She was previously the director at the Oregon Institute of Technology Library and was the liaison librarian for the Mechanical Engineering department. At Oregon Tech, she served as the co-faculty advisor for ASME and SWE. She is a member of ASEE. In her spare time, she drives an NHRA super comp dragster.

\section{Mr. John Burns, Dixie State University}

John Burns is the Reference and Electronic Resources Librarian at Dixie State University in St. George, Utah. He has been a professional librarian for 7 years and enjoys helping students and faculty with research. His current work focuses on reference/research assistance to students, growing collections, developing resources, working with technology, and teaching. 


\title{
Making all the gears drive the machine: New library collections and services for starting a mechanical engineering program
}

\begin{abstract}
A new university program proposal always brings challenges for a subject liaison librarian and for a mid-size library. This is especially true when a new program, such as mechanical engineering, represents an entirely new discipline area. This article will discuss how the Dixie State University (DSU) Library was able to leverage the experience of their new library dean (a former engineering librarian) to mentor a librarian called upon to serve as the new engineering subject liaison.
\end{abstract}

The article will discuss how the engineering librarian and dean performed a thorough collection assessment and had a frank discussion with the program faculty, provost, and others to advocate for resource needs. They were also able to build relationships with new faculty hired to lead the department and hope this relationship building will result in a strong information literacy component within the mechanical engineering curriculum. DSU's library's goals are always to be a strong supportive and teaching supplement to its faculty within a campus environment of student-centered learning and teaching.

Ongoing challenges include defining a core collection in the face of sometimes competing demands such as accreditation, faculty needs, and limited funding. Experiences have shown that patience, skillful communication, concrete evidence, advocacy, and diplomacy reign supreme in a list of virtues necessary to achieve success for all interested parties. The library staff recognize first and foremost that all of their work is ultimately to provide the best opportunity for learning and the continued success of our students. Other libraries would benefit from their experiences in establishing a new engineering collection and services from the ground-up.

\section{Introduction}

The rapid growth of engineering programs across many different types of institutions is well documented. As a recent ASEE Prism [1] article noted, "the growth curve coincides with a national push for STEM education by policymakers at all levels. It also reflects a recessionchastened generation of students seeking a degree that translates to a stable, well-paying job, and widening opportunities for engineers in advanced manufacturing, computer science, and the biomedical and biotechnology fields.” Reflecting this national trend, Dixie State University, a public comprehensive university recently moved from offering a pre-engineering associates program to starting a bachelor of science in mechanical engineering scheduled to begin fall 2018. College leadership chose mechanical over other fields in engineering based on student demand and the support of local industry based on the current and future job market in the area.

This comes during a time of unprecedented growth for DSU, which was granted University status in 2013. In fall 2017, Dixie State had the highest enrollment percentage increase among Utah's public colleges and universities for its second consecutive year. During 2016-2017, consistent with the DSU strategic plan the university added seven new baccalaureate majors and plans to add five more (including mechanical engineering) in the next year, along with its first three master's programs [2]. Balancing the competing needs of existing curriculum while 
recognizing the desire for faculty and administration to expand and offer new programs has been a challenge for the library in terms of collections, services, and funding.

This article will focus specifically on how a medium-sized library, such as DSU, is developing a mechanical engineering collection and expertise without significant startup funding. A model with a five-year timeline for development between a new library dean, a librarian now serving as a new engineering subject liaison, and new program faculty has been developed which can hopefully serve as a model for other schools wishing to develop an engineering collection and services where none existed in the past. This approach allows for a subject liaison to learn the discipline and build a targeted collection in collaboration with instructional faculty while building strong relationships with the department. In addition, this article will discuss how this has prompted a re-evaluation of the process in the library and in the institution for looking at library resources for new program proposals.

\section{Background}

Developing collaboration between instructional faculty and librarians with regard to building collections, especially related to new academic programs, has been an ongoing issue discussed extensively in the literature, but solutions often remain elusive. Cultural and organizational barriers are discussed by Shen [3] including financial, psychological, and communication styles. Wu and Senior [4] surveyed business librarians and found a lack of librarian involvement in new program development in higher education which "can be a reflection of teaching faculty's perception of the campus library." Faculty librarians at DSU have worked tirelessly to enhance positive perceptions and, at times, have needed to educate, inform, and dispel myth while working to build bridges and provide support. New program development, in particular, inspired the librarian now working with the mechanical engineering department, to expand liaison work by joining DSU's campus curriculum committee years ago. This initiative has predominantly served the library well; not only to provide a voice for the library among the faculty, but also to provide opportunity to help guide the process of new program development with regard to library resources. Furthermore, with a librarian on the committee, the other librarians stay informed on what is in the works as information is relayed from the committee meetings to the librarians. The librarian can also take concerns and recommendations back to the committee from the librarians.

Sinha and Tucker [5] discussed the role of the collection development department in the University of Nevada, Las Vegas approval process for new academic programs and provided guidance on tools for assessing the collection. Likewise, at Oregon State University collection assessment has been a required part of the new program review process. This role has grown over time to be more meaningful even when it has not resulted in more funding [6]. It is particularly difficult to create a new area of focus in the library when funds are not allocated as common practice for new programs or in other words, "librarians are expected to do more with less, which is unsustainable, as stagnant budgets cannot keep pace with inflation [4].” This point is of particular concern to librarians at DSU on many levels. Materials budgets have typically been flat at Dixie State University for many years. The DSU Library currently has over 120 databases, 41,000 journals, 130,000 e-books and 100,000 print books. As a member of the Utah Academic Library Consortium (UALC), the library is able to provide access to more electronic 
resources than it would without this valuable collaboration. It also has a small special collections and archive of local history materials. The librarians recognize that while they have a solid collection in most areas, adding distinctly different disciplines requires substantial investment. At DSU there was historically a sense from faculty that asking for additional funding would hurt proposals and in most cases new funding for library resources was not requested, even when a library subject liaison was consulted and recommended resources. Librarians are forced to reallocate funds from existing programs to build new programs to the detriment of all. This is not unique to Dixie State University, as noted by Wu and Senior [4] "most of the time, teaching faculty wait until the whole proposal is already crafted to contact the library. The implied expectation is for the librarian to provide an affirmative statement that 'library resources are adequate.' Sometimes librarians are caught in an awkward position when the expected statement is not true. If they are frank about the need for additional resources (and hence financial support for those resources), they risk damaging the liaison relationship because the proposal could be delayed, even though an affirmative statement is usually not a requirement for final approval.” When a mechanical engineering degree was proposed as an initial white paper, the newly designated engineering liaison prepared a collection analysis with a recommendation that additional resources would be necessary to augment our current holdings. However, this recommendation was disregarded and the initial program proposal contained no library materials supplementation beyond Google Scholar and interlibrary loan and a note that further resources would be pursued if demand arose.

In addition to challenges with collections, being asked to be do more with less also leads to capacity issues with staffing. The DSU Library has 6 tenured or tenure track faculty librarians who all have subject liaison responsibilities, as well as functional responsibilities. As a comprehensive university with heavy workload responsibilities for teaching and service, all librarians participate extensively in campus wide and other professional commitments. In the case of mechanical engineering, an existing science librarian was asked to assume mechanical engineering subject area responsibilities with little background in the area. This challenge will need to be addressed, especially as the first ever master's programs and further new programs are continued to be added and other projects and initiatives continue to compete for librarian time and attention. Staffing models which have been in place for twenty years are no longer viable and new models have to be considered.

\section{Objectives}

Early in the program proposal process DSU hired a new dean of library and learning services with a background in engineering and a familiarity with ABET accreditation. After discussing the proposal with the subject liaison, she agreed on the inadequacy of the current collection to support an engineering curriculum and began mentoring the subject liaison and working with the new program faculty to create a sustainable plan for development. For instance, of the 130 print books in this subject area owned by the library, 104 were greater than 10 years old and less than 500 e-books were in our catalog. While fortunate to have both ScienceDirect and Web of Knowledge/Web of Science the library did not have a specialized engineering resource. To meet its mission, the library needs to provide adequate resources to support quality programs and if it 
is to meet the university strategic goal of moving from receiving status to stature of a university, planning for long term support for library resources must be included.

While planning for mechanical engineering was a large project, there were also several other program proposals being prepared at the same time. It quickly became evident that the workload of subject liaisons preparing these collection assessments needed to be addressed. A plan for preparing collection assessments would have to be developed which allowed for adequate preparation time and librarian input earlier in the process. In some cases, librarians had been given less than a week to prepare recommendations and this was causing undue stress and resulted in an uneven quality of reports.

\section{Description}

As in-person planning meetings took place; the library portion of the mechanical engineering program proposal became an iterative process. These meetings were important on a number of levels including relationship building with new faculty and seeing librarians as partners to strengthen the program. This was also an excellent opportunity to begin discussions of where to embed critical thinking and information literacy into the curriculum from the beginning. From these discussions, the library dean and subject liaison were able to gain a much clearer idea both of the focus and the vision of the program which would differentiate our institution from others in the state and region. While students will complete a rigorous program in core mechanical engineering courses, this program will be specifically strong in the areas of mechatronics, the internet of things, and design and manufacturing. With this in mind, the library's collection development efforts will better represent the nature of the program. DSU's provost also had a key role in communicating the importance of library resources and his support of including funding of library resources in program proposals when necessary. This was critically important in dispelling the sense that departments shouldn't include additional funding for library resources even when clearly justified. Although funding is tight at the institution, having this direction and support from the provost for building library collections is appreciated.

The final mechanical engineering program proposal approved by the curriculum committee and academic council is financially realistic, and as a 2012 ARL Issue Brief [7] stated "an effort to increase efficiencies in expenditure, so libraries will move from collecting material in anticipation of its use to resource management that is more directly responsive to expressed, explicit user need.” It includes a five-year plan, which will build out resources with the program curriculum, and as the program grows. Purchases are tied to a curriculum map (appendix A) developed by the department while still allowing for flexibility by the subject liaison. For instance, the library dean recognized standards probably wouldn't be extensively used until Product Design I and II in year 4. At that time a standards database would be particularly important as students would be completing a culminating design project. In this way, ongoing costs could be built into the library base budget over time instead of incurring large startup costs in the library along with large lab startup costs. From a library perspective, staff would prefer to have all information and research resources immediately available before students are admitted, but being willing to compromise will ultimately be in the best interest of the students and will result in a stronger program. The result is a clearly communicated five-year plan that 
administration and all constituents are committed to and we will be ultimately ready for ABET accreditation. Because relationships have been established this plan can adapt if the program changes.

\section{Plan}

\begin{tabular}{|l|l|l|}
\hline Year & Resources & $\begin{array}{l}\text { Percentage of total allocation } \\
\text { for program }\end{array}$ \\
\hline $1-2$ & Core collection & $30 \%$ \\
\hline $3-4$ & $\begin{array}{l}\text { Electronic Resources: } \\
\text {-ASME Digital Collection } \\
\text {-ASME Standards Collection } \\
\text {-Elsevier's Engineering } \\
\text { Village }\end{array}$ & $30 \%$ \\
& $\begin{array}{l}\text {-Elsevier's Scopus* } \\
\text {-IET's Inspec* } \\
\text {-CRCnetBase* }\end{array}$ & \\
\hline $4-5$ & -IEEE Xplore Digital Library & $40 \%$ \\
\hline
\end{tabular}

\section{Details}

Year 1-2:

The library will purchase a core collection of books and journals. This will mean continuing to work together to create a shared understanding and definition of what a core collection means to all of the stakeholders. This is complicated by the fact that the concept of core varies from institution to institution and no standard list of resources exists [8]. In addition to building a core collection of classic works, topics specifically focused on for collection development will include statics, dynamics, materials, and manufacturing to coincide with the curriculum map. The first classes will be Intro. to Design and Prototyping, Coding, Manuf. Processing and Prototyping Techniques which will lead to a Maker Certificate (pending approval). Therefore, many of the library's first book purchases and research guides will focus on topics such as learning Raspberry Pi, Arduino, additive manufacturing, SOLIDWORKS, and other CAD/CAM Design software.

\section{Year 3-4:}

The library will add specialized engineering databases with research resources comparable to other institutions and fund mechanical engineering at a level comparable to other departments at DSU. Collection development focus areas will be systems \& controls, fluid mechanics, strengths of materials, and machine design.

* Utah Academic Library Consortium 2018 legislative budget request for funding to provide access to all Utah academic libraries. 


\section{Year 4-5:}

The library will add IEEE or other comprehensive electrical and electronics engineering database with extensive standards available.

As this collection development plan is implemented, mentoring of the subject liaison librarian is increasingly more important to be aware of resources such as ASEE-ELD. Davidson and Middleton [9] found that "sci-tech librarians consider professional associations invaluable to professional growth and continued learning in the field.” In addition, “ASEE-ELD members appear to be the most engaged as mentors and mentees.” However, in the dean's experience it was difficult for a new engineering librarian to know of the professional associations for engineering librarians and hard to find the time to commit to exploring options in-depth. Connecting and networking with peers is the best way to learn the field but this can be difficult when other duties are so pressing and demanding. Specialized knowledge of patents, standards, government publications, and technical reports is difficult to gain from independent reading or library conference attendance alone. Clearly in engineering and other highly technical fields, "the base level of knowledge that a liaison must possess is much broader than familiarity with a reference collection or facility with online searching; instead, they must constantly keep up with evolving pedagogies and research methods, rapidly developing tools, technologies, and everchanging policies that facilitate and inform teaching, learning, and research in their assigned disciplines [10].” Further professional development for the library liaison in addition to organizational membership could include participation by audit in an engineering fundamentals or other similar course. Alternatively, once the maker certificate is approved, the liaison could benefit from acquiring the certificate.

\section{Results /Evaluation}

The important outgrowth of developing a new program as significant as a B.S. of mechanical engineering is that it has prompted the institution to re-evaluate the process for new program reviews. Faculty are now given a packet detailing both program accreditation and NWCCU relevant sections including library information. The DSU Library is now explicitly included in the process. As part of this new program review process, faculty are instructed to contact the library dean to be referred to the appropriate subject liaison librarian as soon as they start the full proposal writing process. The information packet also now states that it can take several weeks to do a review of library needs. This is a significant improvement from the past. Instructions are further given that if additional library resources are needed for a new program, the library will provide recommendations and information to use in the proposal. Statements that no library resources are needed must be confirmed by the subject liaison and the library dean. Librarian representation on the university curriculum committee is showing demonstrable value to the campus as well. Although this is an ex-officio position, even as non-voting member, a librarian can answer questions, and provide clarification and feedback. Currently this position is held by the mechanical engineering subject liaison librarian, which was particularly helpful when faculty members had library resource questions when the proposal came before the committee. 
The library dean is included in the governance of campus and is part of academic council and deans' council. This committee representation is particularly advantageous when it comes to explaining library resource cost, including inflationary increases. While this is always going to be a challenge, especially with high cost journals and databases, a recognition of realistic costs with the dean of the college of science and technology has been established and now both deans are working together to explore alternative sources of funding.

Within the library a structure has also been developed for program proposal reviews which can be replicated for future new programs requiring extensive resource development based on our experiences with mechanical engineering. A template which draws on the work of [5] for collection analyses is in process. Common elements include average journal costs by discipline, standard language on limits to interlibrary loan due to copyright and other restrictions, increased costs for document delivery services, etc. The library management team also agreed on getting estimated costs from other libraries to include on the proposal. Information on Open Access resources will also be included as a standard item as a chance to begin a dialogue with faculty. They will also include information on how to include student and faculty research in an institutional repository. As a comprehensive university, the primary mission is teaching. However, as DSU offers more STEM majors such as engineering, applied research is becoming more of a focus at the institution and librarians will want to stress with faculty the importance of archiving and disseminating their scholarly work through the library.

The library has also implemented, or is in the process of implementing, changes in structure to accommodate enhanced liaison responsibilities library wide. Recognizing that relationships are critical and that the subject liaison librarians need to be more embedded in departments, the library dean is actively looking at tasks, which staff can assume with proper training. One of these is changing our reference model to be a more consultative service with professional staff serving at the reference desk for the first time at the institution. Pursuing more staffing to reduce the burden on current liaisons is ongoing. Future staffing needs could include the need for selected "superliaisons". These are "functional specialists who do not have liaison assignments to specific academic departments but instead serve as "superliaisons" to other librarians and to the entire campus [10].” These experts focus on areas such as data management, copyright, and other emerging areas. For a midsize but rapidly growing institution and library, this could help with making data driven decisions. Subject liaisons will need support to continue to be embedded in specialized fields such as engineering, especially as the institutions expands and grows programs.

\section{Conclusion(s)}

A new subject liaison can learn a good deal about collection development by reading seminal works such as the book edited by Conkling and Messer. The article by Brin [8] is particularly useful for libraries such as DSU's, given that it focuses on medium-sized libraries building collections to support new programs. However, these often assume at least a basic level of knowledge of the discipline on the part of the liaison and a generous level of funding. The DSU library's experience was different and may help others in similar circumstances. The library dean and subject liaison successfully worked with program faculty to create a roadmap, combined 
with sustainable funding, to build both a collection and expertise in mechanical engineering. A five year timeline was determined to be a reasonable timeframe for implementation as this coincided with the build out of the program. The relationships built will contribute to the ultimate success of the library and program collaboration. In addition, this program proposal prompted several important changes at the library and institutional level, which will positively impact library involvement in further program proposal development. 


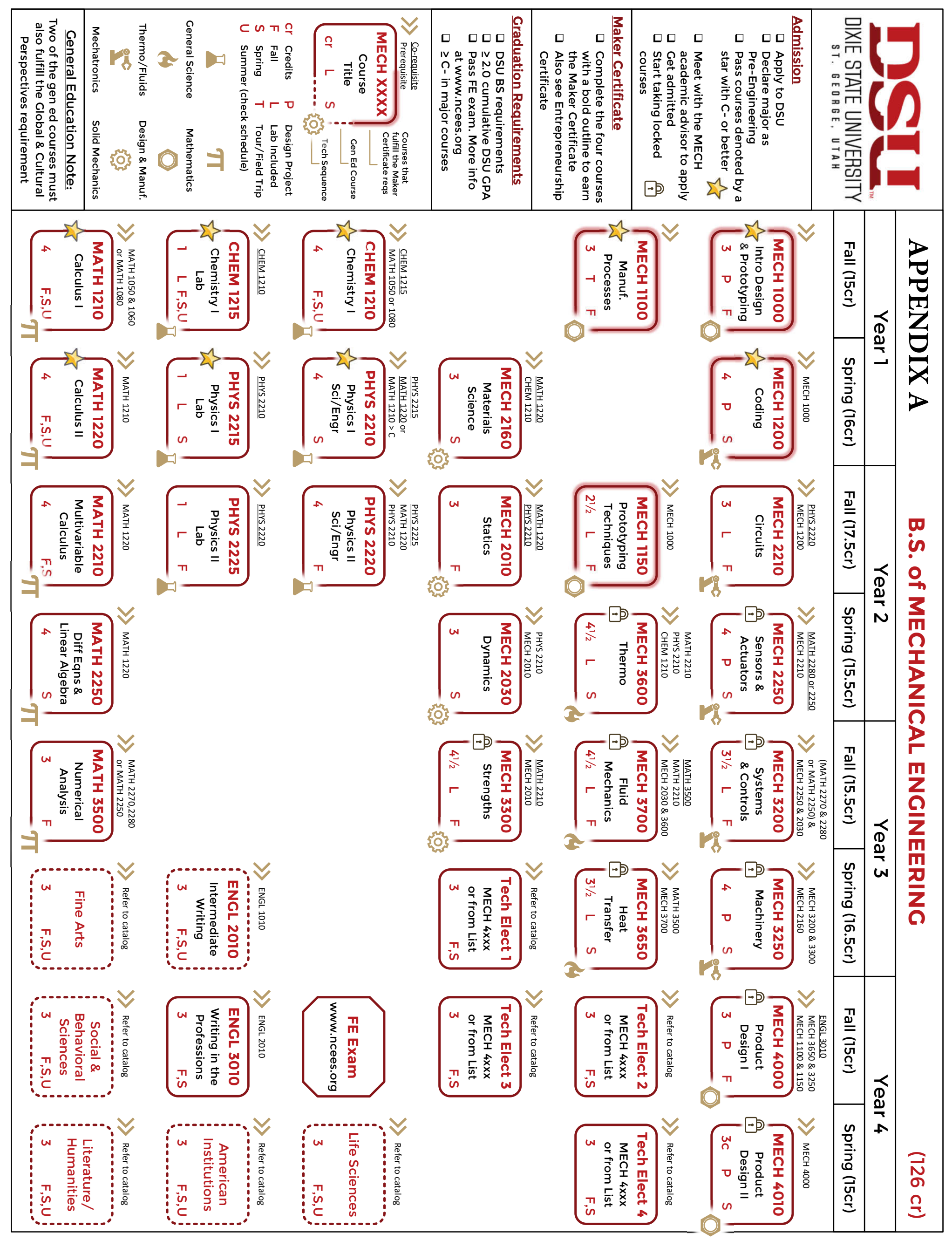




\section{Acknowledgment}

The authors would like to thank Kathleen Broeder, Emma Lanners, Rob Gray and Braxton

Thornley for their generous help and valuable feedback. The authors would also like to acknowledge the contribution of David Christensen for preparing the curriculum map included in the appendix.

\section{References}

[1] M. Matthews and J. Pocock, “Building boom,” ASEE Prism, May 2017. [Online]. Available: http://www.asee-prism.org/building-boom/. [Accessed Jan. 1, 2018].

[2] "DSU shows highest enrollment increase percentage in Utah for two years running," University News, October 11, 2017. [Online]. Available: https://news.dixie.edu/2017/10/11/dsushows-highest-enrollment-increase-percentage-in-utah-for-two-years-running/. [Accessed: Jan. 5, 2018].

[3] L. Shen, "Improving the Effectiveness of Librarian-Faculty Collaboration on Library Collection Development," Collaborative Librarianship, vol. 4, iss. 1, article 3. 2012. Available: https://digitalcommons.du.edu/collaborativelibrarianship/vol4/iss1/3. [Accessed: Jan. 2, 2018].

[4] K. Wu and H. Senior, "Business librarians and new academic program review," Journal Of Business \& Finance Librarianship, vol. 21, no. 2, p. 114-134, 2016. [Online]. Available: http://pdxscholar.library.pdx.edu/cgi/viewcontent.cgi?article=1240\&context=ulib_fac. [Accessed: Jan. 2, 2018].

[5] R. Sinha and C. Tucker, "New program growth and its impact on collection assessment at the UNLV Libraries,” Library Hi Tech, vol. 23, no. 3, p. 362-371, 2005. [Online]. Available:https://pdfs.semanticscholar.org/f071/eab8ed8576899e8d93cc286fbb1d587b4c80.pdf. [Accessed Dec. 27, 2017].

[6]A.M. Bobal, M. Mellinger, and B.E. Avery, "Collection assessment and new academic programs,” Collection Management, vol. 33 no. 4, pp. 288-301, 2008. [Online]. Available: https://ir.library.oregonstate.edu/downloads/ww72bc50w. [Accessed Dec. 07, 2017].

[7] Association of Research Libraries, "21st-Century Collections: Calibration of Investment and Collaborative Action,” 2012. [Online]. Available: http://www.arl.org/publicationsresources/2021-21st-century-collections-calibration-of-investment-and-collaborativeaction\#.WkWN3iRlChA. [Accessed: Dec. 28, 2017].

[8] B. Brin, "Building a Library Collection to Support New Engineering Programs,” in Engineering libraries: building collections and delivering services, T. W. Conkling and L. R. Musser, Eds. New York, Taylor and Francis, 2002, pp. 46-78. [Online]. Available: Proquest ebook. 
[9] J. R. Davidson and C. A. Middleton, "Networking, Networking, Networking: The Role of Professional Association Memberships in Mentoring and Retention of Science Librarians," Science \& Technology Libraries, vol. 27 no. 1-2, pp. 203-224, 2006.

[10] J. Jaguszewski and K. Williams, "New Roles for New Times: Transforming Liaison Roles in Research Libraries," Association of Research Libraries, 2013. [Online]. Available: http://hdl.handle.net/11299/169867. [Accessed: Dec. 28, 2017]. 